\title{
Detection, Identification and Characterization of Some Heavy Metals Tolerant Bacteria
}

\author{
Alaa A Mihdhir ${ }^{1}$, Abdulrahman SA Assaeedi ${ }^{1}$, Hussein H Abulreesh ${ }^{1 *}$ and Gamal EH Osman ${ }^{1,2}$ \\ ${ }^{1}$ Department of Biology, Faculty of Applied Science, Umm Al-Qura University, Makkah, Saudi Arabia \\ ${ }^{2}$ Agricultural Genetic Engineering Research Institute (AGERI), Egypt
}

\begin{abstract}
The threat of heavy metals pollution to public health and wildlife has led to an increased interest in developing systems that can remove or neutralize its toxic effects in industrial effluents and municipal wastewater. Tolerance to a range of heavy metal ions was determined for bacteria which had been isolated from wastewater collected from Makkah city, Saudi Arabia. Isolates were tolerant to cupper, cadmium, zinc, and cobalt although the levels of tolerance to the different concentrations of metal ions were specific for each isolate. One isolate was able to tolerate all four metal ions tested; phenotypic and genotypic investigation revealed that isolate (S7) resembled similarities with Pseudomonas aeruginosa. The results of this study showed the potential applicability of the isolated heavy metal-tolerant strain Pseudomonas aeruginosa (S7) in the treatment of heavy metal containing solutions. Further studies on the genomic structure of isolate (S7) are required to investigate its capabilities to remove/reduce heavy metals in contaminated microcosms.
\end{abstract}

Keywords: Heavy metals; Tolerance; Pseudomonas areuginosa; PCR; $16 \mathrm{~S}$ rRNA genes

\section{Introduction}

In developed agricultural systems, inorganic fertilizers are applied to the soil to supply the essential nutrients required for the growth of plants. Many agricultural and industrial practices have led to substantial release of toxic heavy metal ions in the environment; such practices include direct application of animal wastes that may contain high concentrations of heavy metals to agricultural land, or irrigating agricultural land with untreated wastewater [1]. Accumulated heavy metals in the environment constitute potential health hazards to humans, harm to living resources and ecological systems [2,3]. Heavy metals including cadmium $\left(\mathrm{Cd}^{++}\right)$, lead $\left(\mathrm{Pb}^{++}\right)$, zinc $\left(\mathrm{Zn}^{++}\right)$, mercury $\left(\mathrm{Hg}^{++}\right)$, cupper $\left(\mathrm{Cu}^{++}\right)$, cobalt $\left(\mathrm{Co}^{++}\right)$and nickel $\left(\mathrm{Ni}^{++}\right)$, which act as soluble compounds or exchangeable elements represent a risk of toxicity depending on the rate of transfer from polluted areas to soil solution, plants, ground water, soil microflora and to the food chains [4].

Heavy metals are difficult to remove from the environment and unlike many other pollutants cannot be chemically or biologically degraded and are ultimately indestructible [5]. Heavy metal ions often damage viable cells severely even if they play essential roles on many metabolic processes at low concentration [6]. The threat of heavy metal pollution to public health and wildlife has led to an increased interest in developing systems that can remove or neutralize its toxic effects in soil, sediments and wastewater [7].

Microbial populations in metal polluted environments contain microorganisms which have been adapted to toxic concentrations of heavy metals and become metal resistant. Such microorganisms have developed diverse mechanisms for survival in the presence of heavy metals, and acquired genetic properties that counteract the effects of high metal ion concentrations $[4,8]$. The use of heavy metal resistant microorganisms for the decontamination of heavy metals from contaminated water and soil has attracted growing attention because of several problems associated with pollutant removal using conventional methods $[4,8]$.

The aim of current study was to determine whether the bacteria, isolated from a heavy metals-contaminated industrial wastewater, had adapted to high levels of heavy metals in their microenvironment.

\section{Methods}

\section{Isolation of bacteria}

Water samples were taken from industrial wastewater ponds found in Makkah City, Saudi Arabia. The samples were collected in sterile screw-capped bottles containing $0.1 \%$ sodium thiosulfate to prevent bacterial oxidation. The collected samples were preserved in an ice box and transported to laboratory for direct bacteriological examination. Plate dilution method was employed for bacterial isolation [9] using $\mathrm{LB}$ agar supplemented with $0.5 \mathrm{mM}$ of $\mathrm{Cu}\left(\mathrm{NO}_{3}\right)_{2}, \mathrm{CdCl}_{2}, \mathrm{Zn}\left(\mathrm{NO}_{3}\right)_{2}$ and $\mathrm{Co}\left(\mathrm{NO}_{3}\right)_{2}$ respectively. An aliquot of $50 \mu \mathrm{l}$ of each dilution was spread on the surface of LB agar plates; three replicates of each dilution were prepared. Inoculated plates were incubated at $30-35^{\circ} \mathrm{C}$ for $24-48 \mathrm{~h}$. The O.D. readings of each culture were taken at $0,24,48$ and $72 \mathrm{~h}$. The results were recorded based on three trials for each experiment.

\section{Identification tests}

Random collection of different colonies with various morphological characteristics was selected from LB agar plates. All unknown colonies were subjected to microscopic, biochemical and molecular identification as follows:

Microscopic examination: Gram staining technique was carried out as described by Reddy et al. [9].

Biochemical characterization: Biochemical testes included: Oxidase, Catalase tests, Fermentation of Sugars, Urease test, IMVIC Test, aesculine hydrolysis, gelatin hydrolysis were carried out according to Reddy et al. [9].

*Corresponding author: Hussein $\mathrm{H}$ Abulreesh, Department of Biology, Faculty of Applied Science, Umm Al-Qura University, Makkah, Saudi Arabia, Tel: +966555519597; E-mail: hhabulreesh@uqu.edu.sa

Received May 14, 2016; Accepted May 25, 2016; Published June 04, 2016

Citation: Mihdhir AA, Assaeedi ASA, Abulreesh HH, Osman GEH (2016) Detection, Identification and Characterization of Some Heavy Metals Tolerant Bacteria. J Microb Biochem Technol 8: 226-230. doi: 10.4172/1948-5948.1000290

Copyright: (c) 2016 Mindhir AA, et al. This is an open-access article distributed under the terms of the Creative Commons Attribution License, which permits unrestricted use, distribution, and reproduction in any medium, provided the original author and source are credited. 
Genomic DNA isolation: Genomic DNA was isolated as described by $[10,11]$ and analyzed by horizontal gel electrophoresis in $1 \%$ agarose.

\section{Polymerase Chain Reaction (PCR) Amplification of 16S rRNA}

A universal primer was used for amplifying bacterial $16 \mathrm{~S}$ rRNA genes for nine isolates. 16S rRNA primer (9F - positions 9-27) and (1542R - positions 1542-1525), were synthesized according to Yoon et al. [12] (Table 1$)$. The PCR reaction mixture (50 $\mu \mathrm{L}$ total volume) contained $200 \mu \mathrm{M}$ of each dNTP, $0.5 \mu \mathrm{M}$ primers, $10 \mathrm{mM}$ tris- $\mathrm{HCl}$ ( $\mathrm{pH} 8.3$ ), $1.5 \mathrm{mM} \mathrm{MgCl}, 50 \mathrm{mM} \mathrm{KCl}, 2.5 \mathrm{U}$ Taq polymerase (ABgene, Surry, UK) and $100 \mathrm{ng}$ of template DNA. Amplification of DNA was performed at the following temperature cycle: denaturation at $94^{\circ} \mathrm{C}$ for $3 \mathrm{~min}, 30$ cycles at $94^{\circ} \mathrm{C}$ for $60 \mathrm{~s}, 45^{\circ} \mathrm{C}$ for $60 \mathrm{~s}$, and $72^{\circ} \mathrm{C}$ for $60 \mathrm{~s}$, and final extension at $72^{\circ} \mathrm{C}$ for $7 \mathrm{~min}$. The full-length PCR product size of the $16 \mathrm{~S}$ rRNA genes $(1.3 \mathrm{~kb})$ were investigated using electrophoresis in a $1 \%$ agarose gel.

\section{Sequencing of Amplified Fragments of Isolate (S7) 16S rRNA Genes}

Isolate (S7) is the only isolate that was able to grow in the presence of all four tested heavy metals, thus, it was subjected to further molecular identification. Amplified fragments of the 16s rRNA genes for isolate

\begin{tabular}{|c|c|c|c|}
$\begin{array}{c}\text { Primer } \\
\text { name }\end{array}$ & sequence & $\begin{array}{c}\text { Product } \\
\text { size }\end{array}$ & References \\
\hline 9F & 5'-GAGTTTGATCCTGGCTCAG-3' & 1540 & [12] \\
\hline 1542R & 5'-AGAAAGGAGGTGATCCAGCC-3' & & \\
\hline
\end{tabular}

Table 1: Primer sequence of $16 \mathrm{~S}$ rRNA gene.

\begin{tabular}{|c|c|c|}
\hline $\begin{array}{c}\text { Isolate } \\
\text { number }\end{array}$ & Gram stain reaction & Cell morphology \\
\hline S1 & Gram positive & Staphylococci \\
\hline S2 & Gram positive & Streptobacilli \\
\hline S3 & Gram positive & Streptobacilli (spore former) \\
\hline S4 & Gram positive & Diplobacilli \\
\hline S5 & Gram negative & Short rods \\
\hline S7 & Gram negative & Short rods \\
\hline S8 & Gram negative & Short rods \\
\hline S9 & Gram negative & Short rods \\
\hline
\end{tabular}

Table 2: Gram stain reaction and morphological features of nine selected isolates recovered from industrial wastewater.

\begin{tabular}{|c|c|c|}
\hline Isolate number & Tolerance to heavy metals & Incubation period \\
\hline S1 & No tolerance & $72 \mathrm{~h}$ \\
\hline S2 & Zinc and cobalt & $72 \mathrm{~h}$ \\
\hline S3 & Cuopper & $72 \mathrm{~h}$ \\
\hline S4 & Zinc and cadmium & $72 \mathrm{~h}$ \\
\hline S5 & No tolerance & $72 \mathrm{~h}$ \\
\hline S6 & Cupper & $72 \mathrm{~h}$ \\
\hline S7 & Cupper, cadmium, zinc and cobalt & $72 \mathrm{~h}$ \\
\hline S8 & Cupper and cadmium & $72 \mathrm{~h}$ \\
\hline S9 & Zinc & $72 \mathrm{~h}$ \\
\hline
\end{tabular}

$\ddagger$ Heavy metals concentrations used: $50,75,100,150,200,250,300$ and 350 ppm † Heavy metals used: $\mathrm{Cu}\left(\mathrm{NO}_{3}\right)_{2}, \mathrm{CdCl}_{2}, \mathrm{Zn}\left(\mathrm{NO}_{3}\right)_{2}, \mathrm{Co}\left(\mathrm{NO}_{3}\right)_{2}$

O.D. readings were taken at $0,24,48$ and $72 \mathrm{~h}$

Table 3: The ability of nine isolates to grow and tolerate various concentrations $\ddagger$ of different heavy metals $\uparrow$.
(S7) were cloned into T-easy vector (from Promega, Madison, USA) and the DNA sequences were determined according to the procedure described by Sanger et al. [13].

\section{Preparation of Bacterial Suspensions for Measuring MICs}

The Minimum Inhibitory Concentrations (MICs) of isolate (S7) was carried out according to Lambert and Pearson [14]. The isolated strain was grown overnight in LB broth supplemented with serial concentration of $\mathrm{Cu}\left(\mathrm{NO}_{3}\right)_{2}, \mathrm{CdCl}_{2}, \mathrm{Zn}\left(\mathrm{NO}_{3}\right)_{2}$, and $\mathrm{Co}\left(\mathrm{NO}_{3}\right)_{2}$, with shaking at $35^{\circ} \mathrm{C}, 200 \mathrm{rpm}$, for $24-48 \mathrm{~h}$. The O.D. readings of each culture were taken at $0,24,48$ and $72 \mathrm{~h}$. The results were recorded based on three trials for each experiment.

\section{Results}

A total of one hundred bacterial isolate were selected from all industrial wastewater samples and examined for cell shapes and arrangements. Nine isolates representing various morphological shapes, cell arrangements and Gram stain reaction (Table 2) were tested for their ability to grow in the presence of $\mathrm{Cu}, \mathrm{Cd}, \mathrm{Zn}$ and $\mathrm{Co}$, as shown in Table 3; isolate (S7) was able to grow in the presence of all four tested metals. Thus, it has been selected for further biochemical and molecular identification. The phenotypic characteristics of isolate (S7) showed to be a Gram-negative, motile and aerobic short rod. The isolate is positive for fluorescent pigment under UV light, and gave positive reaction to oxidase, catalase, arginine dihydrolase, urease tests, gelatin hydrolysis, and indole production (Table 4).

\section{Characteristics of isolate (S7) growing in the presence of heavy metals}

We tested isolate (S7) to grow in various concentrations of each of the four heavy metals used (zinc: 100, 200, 250 and 300 ppm), (cupper: 50, 75, $150 \mathrm{ppm}$ ), (cadmium: 100, $250 \mathrm{ppm}$ ) and (cobalt: 100, 200, 350 $\mathrm{ppm}$ ). As shown in Figure 1, isolate (S7) was able to tolerate $100 \mathrm{ppm}$ of all tested heavy metals during $72 \mathrm{~h}$ incubation. When the concentration of heavy metals increased over $100 \mathrm{ppm}$ (i.e., $150-350 \mathrm{ppm}$ ), there was

\begin{tabular}{|c|c|}
\hline & Strain No. \\
\hline & S7 \\
\hline Gram staining & Gram Negative \\
\hline Oxidase & + \\
\hline Gelatin Hydrolysis & + \\
\hline Urease & + \\
\hline Arginine Dehydrolase & + \\
\hline Citrate utilization & + \\
\hline Lysine Decarboxylase & - \\
\hline Aesculine hydrolysis & - \\
\hline $\mathrm{NO}_{3}$ reduction to $\mathrm{N}_{2}$ & + \\
\hline $\mathrm{NO}_{3}$ reduction to $\mathrm{NO}_{2}$ & - \\
\hline Indole production & - \\
\hline Glucose (fermentation) & - \\
\hline Glucose (Assimilation) & + \\
\hline Xylose (Assimilation) & + \\
\hline Maltose (Assimilation) & - \\
\hline Arabinose (Assimilation) & + \\
\hline Mannose (Assimilation) & + \\
\hline Lactose (Assimilation) & - \\
\hline Growth at $42 \mathrm{C}$ & + \\
\hline
\end{tabular}

Table 4: Phenotypic characteristics of isolate (S7). 
a rapid decline of bacterial growth over the time. Isolate (S7) showed no decline in growth even after $72 \mathrm{~h}$ of incubation in the presence of low concentrations of heavy metals (i.e., less than $100 \mathrm{ppm}$ ) (Figure 1).

Determination of the minimum inhibitory concentration (MICs) for isolate (S7): The Minimum Inhibitory Concentrations (MICs) of isolate (S7) against each heavy metal tested are shown in Table 5. The highest level of tolerance was shown in the presence of cupper $(\approx 134$ $\mathrm{ppm}$ ), followed by zinc and cadmium $(\approx 230$ and $231 \mathrm{ppm}$ ) respectively and finally to cobalt $(\approx 339 \mathrm{ppm})$.

\section{Amplification of $16 \mathrm{~S}$ rRNA genes}

PCR amplification of the $16 \mathrm{~S}$ rRNA of all nine isolates was performed using one pair of universal bacterial primer (Table 1). The results showed that isolates (S7) yielded an amplified fragment with $1540 \mathrm{bp}$ in length which was the expected product size (Figure 2). It is worth mentioning that DNA sequencing of PCR products of isolate (S7) showed that the isolate was found to share $98 \%$ similarity with Pseudomonas aeruginosa (GenBank Accession number KX214297) (Figure 3).

\section{Discussion}

Bacteria may be able to tolerate certain level of heavy metal concentrations in their contaminated microenvironments, such bacterial species can be potential candidates for heavy metal removal from contaminated habitats. Based on data obtained in the current study, high levels of tolerance to heavy metals were detected in the majority of isolates $(44.4 \%, \mathrm{n}=9)$, belonging to both gram-positive and gram-negative genera. The isolate (S7) was able to grow in the presence of all four heavy metals tested $(\mathrm{Cu}, \mathrm{Cd}, \mathrm{Zn}$ and $\mathrm{Co})$ in liquid media. This feature is important for this isolate to have the capacity to survive in different sources of pollution with elevated levels of heavy metals. Isolate (S7) a Gram negative short rod, phenotypically it owed characteristics that resemble Pseudomonas aeruginosa, this finding was further confirmed by the sequencing of the 16S rRNA gene of isolate (S7), which revealed a $98 \%$ similarity to Pseudomonas aeruginosa (Accession number KX214297). Studies of genomic structure of various strains of Pseudomonas aeruginosa showed that the species has various genetic determinants involved in tolerance and resistance to various heavy metals (e.g. mercury, chromium, cadmium, zinc and copper) [15-17].

The MICs determination indicated that isolate (S7) (Pseudomonas aeruginosa) has developed tolerance with various degrees to all of the metal ions tested. The levels of tolerance shown by isolate (S7) were considerably greater than those reported by [18-20] for the MICs of Pseudomonas aeruginosa. The literatures indicated that tolerance to heavy metals often occurs for a range of metal ions rather than for a specific metal only [19-22]. An Important result of this study is the demonstration of metal biosorption capacity for isolate (S7) which could have the capability of removing significant concentration of $\mathrm{Cu}$,
A

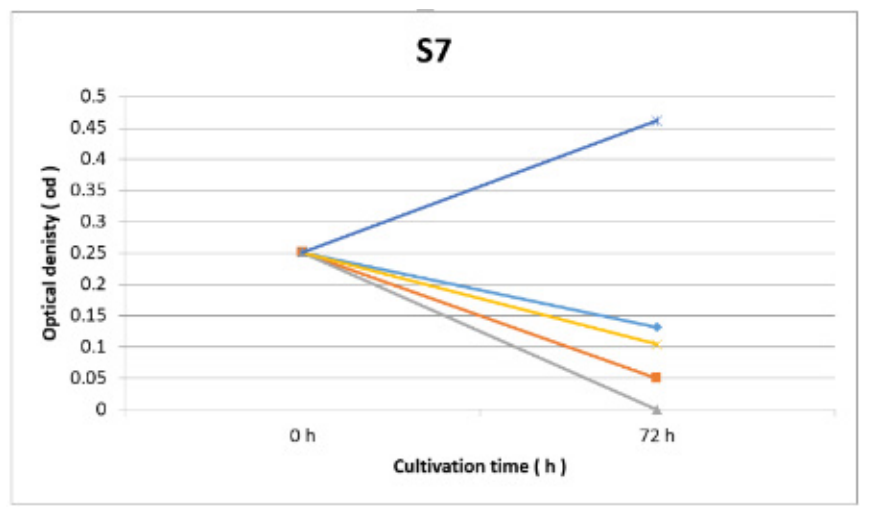

$\mathrm{C}$

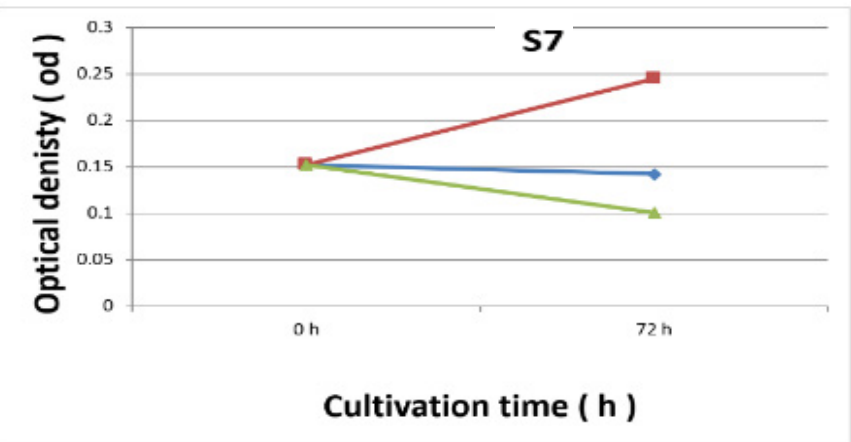

B

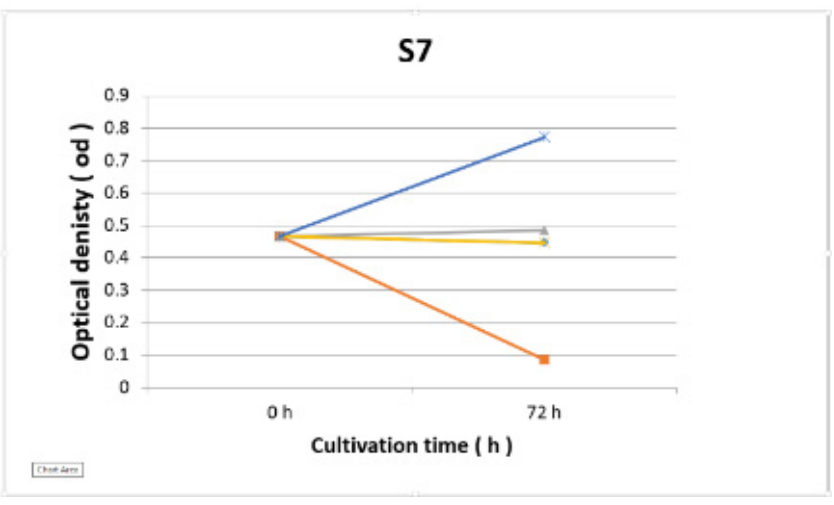

$\mathrm{D}$

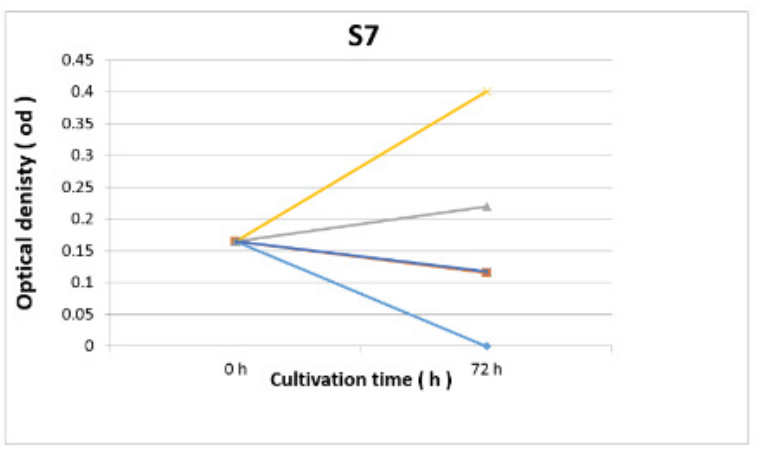

Figure 1: Characteristics of isolate (S7) growth in the presence of:

A: Different concentration of zinc, blue: control, faint blue100, yellow 200, orange 250 and gray 300 ppm.

B: Different concentration of copper, blue control, gray $50 \mathrm{ppm}$, yellow $75 \mathrm{ppm}$ and orange $150 \mathrm{ppm}$.

C: Different concentration of cadmium, red control, blue 100 ppm and green $250 \mathrm{ppm}$.

D: Different concentration of cobalt, yellow control, gray 100 ppm.purple 200 and blue 350 ppm.

The results are based on three trials experiments. O.D. readings were taken at $0,24,48$ and $72 \mathrm{~h}$. 


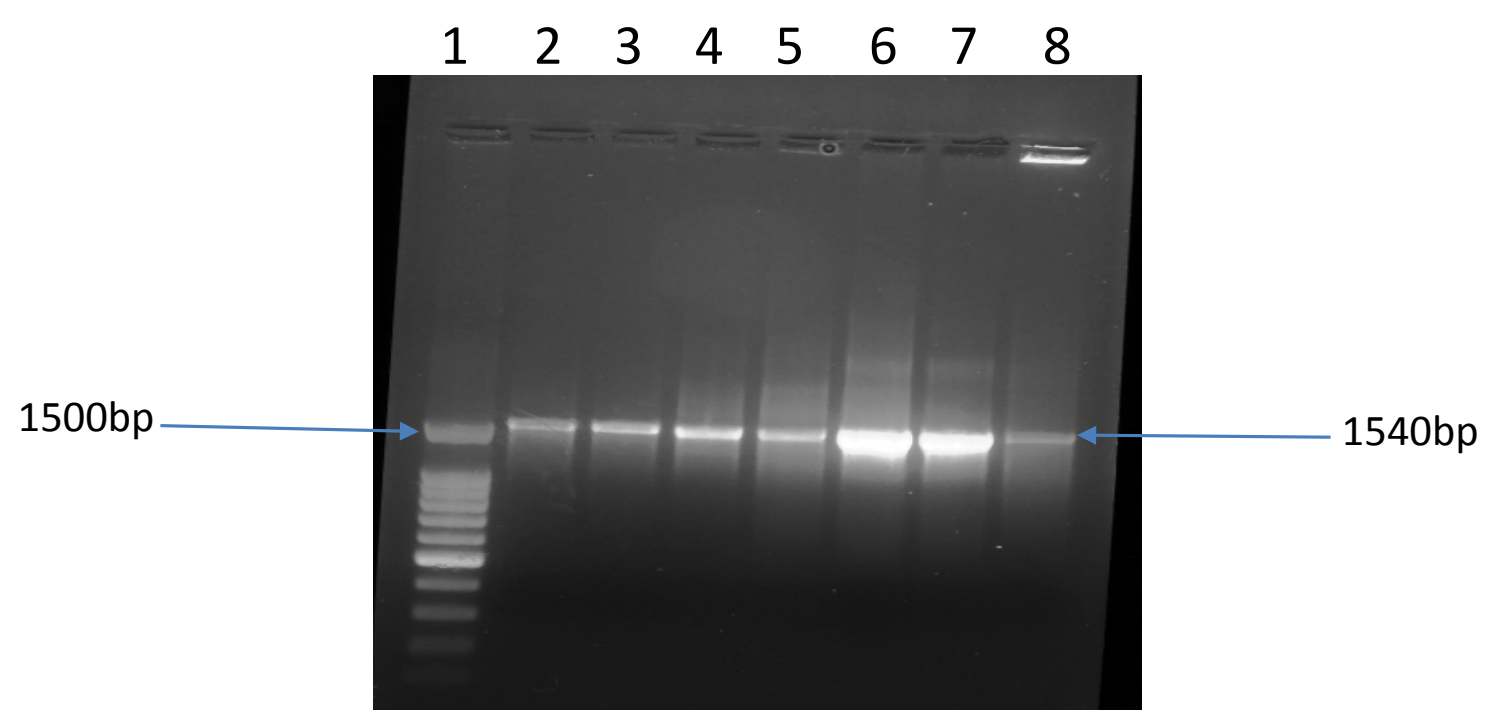

Figure 2: Agarose gel electrophoresis of PCR products of the $16 \mathrm{~S}$ rRNA fragments for isolates number 1, 2, 3, 4, 5, 6 and 7. Lanes 2-8 respectively. Lane 1: DNA Marker. No PCR amplification for isolates 8 and 9.
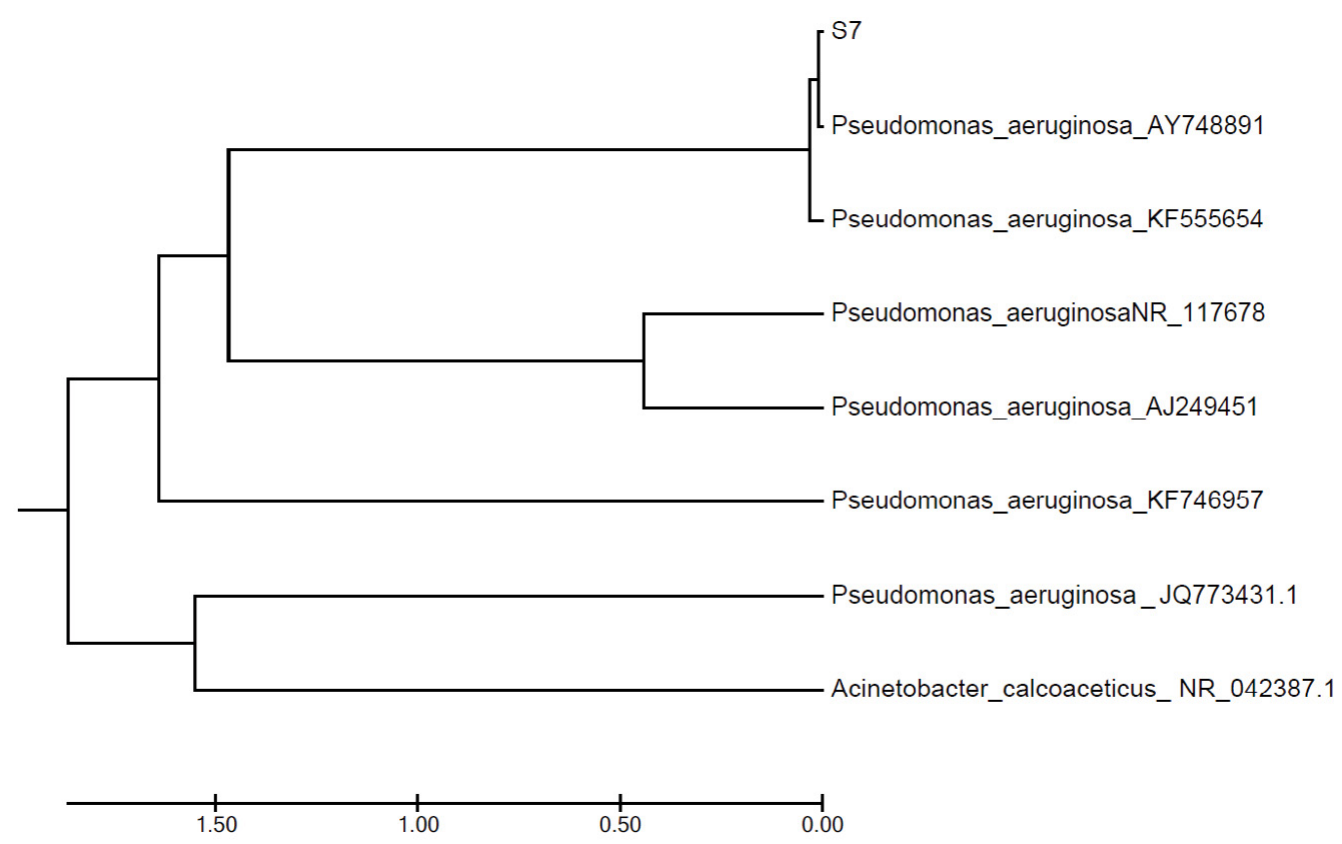

Figure 3: Phylogenetic tree analysis of isolate (S7).

\begin{tabular}{|c|c|c|c|c|c|c|c|c|}
\hline \multirow{2}{*}{ Isolate } & \multicolumn{2}{|c|}{$\mathrm{Cu}\left(\mathrm{NO}_{3}\right)_{2}$} & \multicolumn{2}{|c|}{$\mathrm{CdCl}_{2}$} & \multicolumn{2}{|c|}{$\mathrm{Zn}\left(\mathrm{NO}_{3}\right)_{2}$} & \multicolumn{2}{|c|}{$\mathrm{Co}\left(\mathrm{NO}_{3}\right)_{2}$} \\
\hline & (ppm) & O.D & (ppm) & O.D & (ppm) & O.D & (ppm) & O.D \\
\hline \multirow{7}{*}{$\begin{array}{c}\text { (S7) Pseudomonas } \\
\text { aeruginosa }\end{array}$} & 19.66 & 2.28 & 19.01 & 2.1 & 35.4 & 2.55 & 49.6 & 2.75 \\
\hline & 39.01 & 1.93 & 51.02 & 1.8 & 68.7 & 1.7 & 93.21 & 2.19 \\
\hline & 54.55 & 1.56 & 90.26 & 1.7 & 99.1 & 1.6 & 148.78 & 2.19 \\
\hline & 77.17 & 1.89 & 122.03 & 1.3 & 131.3 & 1.33 & 188.43 & 1.8 \\
\hline & 90.01 & 0.75 & 161.33 & 1.25 & 155.8 & 1.2 & 241.01 & 1.49 \\
\hline & 115.76 & 0.21 & 199.45 & 0.7 & 198.9 & 0.3 & 289.61 & 0.8 \\
\hline & 134.12 & 0.09 & 231.11 & 0.4 & 230.7 & 0.09 & 339.16 & 0.4 \\
\hline
\end{tabular}

† O.D. readings were taken at $0,24,48$ and $72 \mathrm{~h}$.

Table 5: MICs of isolate (S7) For $\mathrm{Cu}\left(\mathrm{NO}_{3}\right)_{2}, \mathrm{CdCl}_{2}, \mathrm{Zn}\left(\mathrm{NO}_{3}\right)_{2}, \mathrm{Co}\left(\mathrm{NO}_{3}\right)_{2} \dagger$. 
$\mathrm{Cd}, \mathrm{Zn}$ and Co during their active growth cycle. This assumption is valid in light of the results obtained in this study and similar results reported elsewhere, were Pseudomonas sp. showed a $97.9 \%$ lead $(\mathrm{Pb})$, 93.5\% cadmium $(\mathrm{Cd})$ and $68 \%$ cupper $(\mathrm{Cu})$ removal efficiency from contaminated industrial wastewater [23].

The results of this study show the potential applicability of the isolated heavy metal-tolerant strain Pseudomonas aeruginosa (S7) in the treatment of heavy metal containing solutions. Further studies on the genomic structure of isolate (S7) are required to investigate its capabilities to remove/reduce heavy metals in contaminated microcosms and isolation and characterization of heavy metal tolerance genes (Supplementary Figures 1-4).

\section{Acknowledgement}

This project was fully funded by Umm Al-Qura University Institute of Scientific Research and Revival of Islamic Heritage (Project number 43205020). We also would like to thank our undergraduate students who participated in this work Mr. Hatem Balkhair, Mr. Khaled Gazi, Mr. Abdullah Alshery and Mr. Meshal H. K. Almalki.

\section{References}

1. Chen Z, Jiang $X(2014)$ Microbiological safety of chicken litter or chicken litterbased organic fertilizers: A review. Agricult 4: 1-29.

2. Inceer H, Ayaz S, Beyazagolu O, Emine S (2003) Cytogenetic effects of copper chloride on the root tip cells of Helianthus annuns. Turk J Biol 27: 43-46.

3. Pepper IL, Gerba CP, Gentry TJ (2015) Environmental Microbiology. (3rdedn), Academic Press, San Diego, USA.

4. Siddiquee S, Rovina K, Al Azad S, Naher L, Suryani S, et al. (2015) Heavy metal contaminants removal from wastewater using the potential filamentous fungi biomass: A review. J Microbial Biochem Technol 7: 384-393.

5. Mejáre M, Bülow L (2001) Metal-binding proteins and peptides in bioremediation and phytoremediation of heavy metals. Trends Biotechnol 19: 67-73.

6. Bozhkov A, Padalko V, Dlubovskaya V, Menzianova N (2010) Resistance to heavy metal toxicity in organisms under chronic exposure. Indian J Exp Biol 48: 679-696

7. Valls M, de Lorenzo V (2002) Exploiting the genetic and biochemical capacities of bacteria for the remediation of heavy metal pollution. FEMS Microbiol Rev 26: 327-338

8. Yang T, Ming-Li C, Jian-Hua W (2015) Genetic and chemical modification of cells for selective separation and analysis of heavy metals of biological and environmental significance. Trends Anal Chem 66: 90-102.
9. Reddy CA, Beveridge TJ, Breznak JA, Marzluf G (2007) Methods for general and molecular microbiology. (3rdedn), ASM Press, ASM, Washington DC.

10. Assaeedi ASA, Abulreesh HH, Osman GEH (2011) The occurrence and insecticidal activity of Bacillus thuringinesis in the arid environments. Austral J Crop Sci 5: 1185-1190.

11. Abulreesh HH, Osman GE, Assaeedi AS (2012) Characterization of insecticida genes of Bacillus thuringiensis strains isolated from arid environments. Indian J Microbiol 52: 500-503.

12. Yoon J, Lee S, Park Y (1998) Inter and intraspecific phylogenitic analysis of the genus Nocardioides and related taxa based on $16 \mathrm{~S}$ rDNA sequences. Int J Syst Bacteriol 48: 187-194.

13. Sanger F, Nickelson S, Coulson AR (1977) DNA sequencing with chain terminating inhibitors. Proc Natl Acad Sci USA 74: 5463- 6467.

14. Lambert RJW, Pearson J (2000) Susceptibility testing: Accurate and reproducible minimum inhibitory concentration (MIC) and non-inhibitory concentration (NIC) values. J Appl Microbiol 88: 784-790.

15. Lee W, Glickmann E, Cooksey DA (2001) Chromosomal locus for cadmium resistance in Pseudomonas putida consisting of a cadmium-transporting ATPase and a MerR family response regulator. Appl Environ Microbiol 67 1437-1444.

16. Hu N, Zhao B (2007) Key genes involved in heavy-metal resistance in Pseudomonas putida CD2. FEMS Microbiol Lett 267: 17-22.

17. Ramírez MI, Díaz A, Mexa V, Johnstone L, Cervantes C, et al. (2011) Nucleotide sequence of $P$ seudomonas aeruginosa conjugative plasmid pUM505 containing virulence and heavy metal resistance genes. Plasmid 66: 7-18.

18. Yilmaz EI (2003) Metal tolerance and biosorption capacity of Bacillus circulans strain EB1. Res Microbiol 154: 409-415.

19. Liu P, Chen X, Huang Q, Chen W (2015) The role of CzcRS two-component systems in the heavy metal resistance of Pseudomonas putida X4. Int $\mathrm{J}$ Molec Sci 16: 17005-17017.

20. Wani $\mathrm{PH}$, Ayoola $\mathrm{OH}$ (2015) Bioreduction on $\mathrm{Cr}(\mathrm{VI})$ by heavy metal resistant Pseudomonas species. J Environ Sci Technol 8: 122-130.

21. Schmidt T, Schlegel HG (1994) Combined nickel-cobalt-cadmium resistance encoded by the ncc locus of Alcaligenes xylosoxidans 31A. J Bacteriol 176 : $7045-7054$

22. Kang C, Wu P Li Y, Ruan B, Zhu N, et al (2014) Estimates of heavy metal tolerance and chromium (VI) reducing ability of Pseudomonas aeruginosa CCTCC AB93066: Chromium (VI) toxicity and environmental parameters optimization. World J Microbiol Biotechnol 30: 2733-2746.

23. Azzam AM, Tawfik A (2015) Removal of heavy metals using bacterial bioflocculants of Bacillus sp. and Pseudomonas sp. J Environ Eng Land Manag 23: $288-294$ 